\title{
Pendidikan Kesehatan Tentang Pemakaian Alat Pelindung Diri Dan Bahaya Pestisida Di Desa Sigambir Kabupaten Brebes
}

\author{
Heni Fa'riatul Aeni ${ }^{1}$, Rif'atun Nisa $^{2}$, Rina Nurfadillah ${ }^{3}$ \\ Sekolah Tinggi Ilmu Kesehatan Cirebon \\ 1email: henifariatulaeni80@gmail.com \\ 2email: rivanisa24@gmail.com \\ 3email: rinastikes123@gmail.com \\ *Corresponding Author
}

\begin{abstract}
ABSTRAK
Kurangnya pengetahuan petani tentang pemakaian Alat Pelindung Diri merupakan dan bahaya pestisida merupakan salah satu penyebab munculnya keracunan, iritasi dan dermatitis. Pemakaian Alat Pelindung Diri merupakan salah satu dari hierarki pengendalian bahaya. Kegiatan ini dilakukan dengan tujuan memberikan pendidikan kesehatan mengenai pemakaian Alat Pelindung Diri dan bahaya pestisida di Desa Sigambir Kecamatan Brebes Kabupaten Brebes Tahun 2019. Metode yang digunakan dalam kegiatan ini dengan cara pendidikan kesehatan melalui penyuluhan/ceramah dan tanya jawab dilanjutkan dengan praktek pemakaian Alat Pelindung Diri dan langkah-langkah pemakaian pestisida. Dari hasil kegiatan yang dilakukan ternyata petani masih memiliki pengetahuan yang rendah tentang pemakaian Alat Pelindung Diri dan bahaya pestisida serta menganggap bahwa memakai Alat Pelindung Diri itu merepotkan dan harganya mahal. Dari kegiatan ini dapat disimpulkan bahwa petani dan pemilik lahan dapat mengetahui tentang manfaat pemakaian Alat Pelindung Diri dan bahaya pemakaian pestisida serta dapat membiasakan untuk memakai Alat Pelindung Diri apa saja yang sebaiknya digunakan saat melakukan penyemprotan.
\end{abstract}

\section{Kata Kunci : Bahaya Pestisida, Pendidikan Kesehatan, Pemakaian APD}

\begin{abstract}
Lack of farmers' knowledge about the use of Personal Protective Equipment is, and the danger of pesticides is one of the causes of poisoning, irritation, and dermatitis. The use of Personal Protective Equipment is one of the hierarchies of hazard control. This activity is carried out to provide health education regarding the use of Personal Protective Equipment and the dangers of pesticides in Sigambir Village, Brebes District, Brebes Regency in 2019. The method used in this activity is by means of health education through counseling/lectures and question and answer, followed by the practice of using Personal Protective Equipment and steps for using pesticides. From the results of the activities carried out, it turns out that farmers still have low knowledge about the use of Personal Protective Equipment and the dangers of pesticides and consider that using Personal Protective Equipment is troublesome and expensive. From this activity, it can be concluded that farmers and landowners can find out about the benefits of using Personal Protective Equipment and the dangers of using pesticides and can get used to using any Personal Protective Equipment that should be used when spraying.
\end{abstract}

Keywords : Hazard of Pesticides, Health Education, Use of PPE 


\section{PENDAHULUAN}

Kesehatan kerja harus mengarahkan pada promosi dan peningkatan derajat kesehatan setinggi-tingginya baik fisik, mental dan sosial yang baik dari tenaga kerja dalam semua jenis pekerjaan dan jabatan; pencegahan bagi tenaga kerja dari gangguan kesehatan yang disebabkan oleh kondisi lingkungan kerja; perlindungan bagi pekerja dalam pekerjaannya dari risiko akibat faktor yang merugikan kesehatan; penempatan dan pemeliharaan tenaga kerja dalam lingkungan kerja yang disesuaikan dengan kemampuan fisiologis dan psikologis; dan kesesuaian kerja pada manusia dan setiap orang pada pekerjaannya.(Soedirman, 2014)

Dalam hal ini, konsep budaya kerja dalam perspektif kesehatan kerja dimaksudkan untuk memberi pengertian tentang berbagai aspek penanganan dan pencegahan penyakit akibat kerja sebagai wujud sistem tata nilai.(Soedirman, 2014)

Saat ini terdapat ribuan senyawa kimia dan campuran yang kebanyakan berbahaya namun secara teknik dapat dikendalikan. Sebagian besar kecelakaan terjadi akibat mengabaikan sifat-sifat bahan kimia yang berkaitan dengan proses.(Cahyono, 2004)

Chemical Safety atau keselamatan bahan kimia adalah upaya untuk melindungi kesehatan manusia dan atau pekerja, fasilitas dan instalasi serta lingkungan di ssemua bagian pekerjaan pada simpul daur hidup bahan kimia dari penyalahgunaan bahan kimia dan pemakaian bahan kimia yang salah.(Universitas Indonesia, 2018)

Bahan kimia banyak dipakai dalam lingkungan industri, yang dapat dibagi dalam dua kelompok besar yaitu satu industri kimia, yaitu industri yang mengolah dan menghasilkan bahanbahan kimia, seperti industri pupuk, asam sulfat, soda, bahan peledak, pestisida, cat, deterjen, dan lainnya. Lingkup perusahaan kimia adalah perusahaan yang memakai proses-proses yang bertalian dengan perubahan kimiawi atau fisik dalam sifat-sifat bahan tersebut dan khususnya pada bagian kimiawi dan komposisi suatu zat. Dua perusahaan pemakai bahan kimia, adalah perusahaan yang memakai bahan kimia sebagai bahan pembantu proses, contohnya perusahaan tekstil, kulit, kertas, pelapisan listrik, pengolahan logam, obat-obatan dan lain-lain.(Cahyono, 2004)

Di tempat kerja, banyak bahan kimia yang terpakai tiap harinya sehingga kemungkinan besar para pekerja bisa terpapar. Bahaya tersebut kemungkinan bisa meningkat dalam kondisi tertentu sesuai dengan sifatnya, seperti mudah terbakar, beracun, dan sebagainya. Semua jenis pekerjaan yang berkaitan dengan bahan kimia memiliki risiko bahaya, mulai dari proses, penyimpanan, transportasi, pendistribusian dan pemakaiannya. Akan tetapi, betapapun besarnya bahaya bahan kimia, penanganan yang benar bisa meminimalisasi atau bahkan mengeliminasi risiko bahaya yang timbul.(Cahyono, 2004) 
Pertanian memiliki kontribusi baik bagi perekonomian maupun bagi pemenuhan kebutuhan pokok masyarakat. Meningkatnya jumlah penduduk membuat kebutuhan pangan semakin tinggi terhadap hasil tanam, salah satunya dengan mengurangi hama yang menyerang tanaman dengan memakai obat kimia pembasmi hama tanaman seperti pestisida, karena tanaman yang sudah terserang hama akan berdampak pada kerusakan tanaman yang dapat mengakibatkan menurunnya nilai jual bahkan sampai mangalami gagal panen. Walaupun memberi dampak baik bagi hasil tanam, pestisida juga bisa memberikan dampak buruk.(Shobib, 2013)

Hampir tiap hari ribuan petani dan para pekerja di sektor pertanian bisa terpapar pestisida dan setiap tahun diperkirakan jutaan orang yang bekerja di pertanian dapat mengalami keracunan akibat pestisida. World Health Organization (WHO) memprediksi pada tahun 2009 di India, sekitar 600.000 kasus dan 60.000 kematian terjadi dan yang paling berisiko adalah anak-anak, perempuan, pekerja di sektor informal dan petani miskin. Pada tahun 2008 di Bangladesh, terjadi keracunan pestisida paling tinggi hingga menyebabkan kematian. Di Kamboja, setidaknya 88\% petani mengalami dampak akut keracunan pestisida, di China, sekitar 53.000 sampai 10.000 mengalami kanker, cacat, mandul, dan hepatitis setiap tahunnya yang merupakan dampak dari pestisida.(Purwati, 2010)

Sebagai Negara agraris, pemakaian pestisida di Indonesia cukup tinggi. Pada tahun 2006 tercatat sekitar 1.336 formulasi dan 402 bahan aktif pestisida sudah terdaftar untuk mengendalikan hama di berbagai bidang komoditi. Pesticide Action Network Asia and the Pasific (PANAP) menyatakan dalam hasil penelitiannya mengenai bahaya pestisida di Wonosobo Jawa Tengah sebagai tempat percontohan untuk pemantauan di wilayah Asia, pada bulan Agustus s/d Oktober 2008 menunjukan bahwa dari 100 responden, ada 6 orang, yang terdiri dari 2 orang perempuan dan 4 orang laki-laki mengalami gangguan kesehatan.(Purwati, 2010)

Hasil penginderaan manusia, atau hasil tahu seseorang terhadap objek lewat indera yang dimilikinya seperti mata, hidung, telinga, dan sebagainya merupakan pengetahuan. Dengan sendirinya pada saat penginderaan sampai menghasilkan pengetahuan sangat dipengaruhi oleh intensitas perhatian dan persepsi terhadap objek. Suatu respon dari seseorang terhadap stimulus secara tertutup atau objek tertentu, yang telah melibatkan faktor pendapat dan emosi (senang-tidak senang, setuju-tidak setuju, baik-tidak baik, dan sebaginya) adalah sikap. Menurut Newcomb yang dikutip oleh Notoatmodjo (1997) bahwa sikap merupakan kesiapan atau kesediaan seseorang untuk bertindak sebagai objek di lingkungan sebagai suatu penghayatan terhadap objek.(Notoatmodjo, 2010b)

Masih banyak para pengguna bahan kimia jenis pestisida khususnya para petani yang sangat minim pengetahuan tentang bagaimana dampak bahan kimia dalam jangka panjang dan 
sikap petani atau pemakai pestisida yang belum mengetahui bagaimana cara pemakaian Alat Pelindung Diri (APD) pada saat pencampuran maupun penyemprotan pestisida.

Brebes adalah salah satu Kabupaten di Provinsi Jawa Tengah yang memiliki luas wilayah 1.902,37 km² dan jumlah penduduk sekitar 1.732.719 jiwa pada data tahun 2010 dengan ibu kota yang terletak di Kecamatan Brebes. Brebes merupakan kabupaten dengan jumlah penduduk terpadat di Jawa Tengah, dan paling luas di Jawa Tengah ke-2 setelah Kabupaten Cilacap. Sektor pertanian merupakan sektor yang dominan di Brebes. Dari sekitar 1,7 juta penduduk Brebes, sekitar 70\% bekerja di sektor pertanian. Sektor ini menyumbang 53\% Produk Domestik Regional Bruto (PDRB) Kabupaten Brebes, dan 50\% dari pertanian bawang merah. Desa Sigambir adalah salah satu Desa yang terletak di Kecamatan Brebes dengan jumlah penduduk 3.509 jiwa dan lebih dari 50 persen penduduknya sebagai petani.(Anonim, 2018)

Hasil penelitian Heni pada tahun 2018 diperoleh bahwa dari 76 responden yang diteliti sebanyak 51,3\% responden memiliki pengetahuan kurang baik tentang Alat Pelindung Diri (APD), $51,3 \%$ responden memiliki sikap negatif dan 98,7\% responden tidak lengkap dalam pemakaian Alat Pelindung Diri (APD).(Aeni \& Nurfadillah, 2018)

Dari uraian diatas penulis memiliki keinginan untuk memberikan pendidikan kesehatan mengenai pemakaian Alat Pelindung Diri (APD) dan bahaya pestisida di Desa Sigambir Kecamatan Brebes Kabupaten Brebes Tahun 2019.

\section{BAHAN DAN METODE}

\section{Alat Pelindung Diri (APD)}

Alat atau kelengkapan yang wajib digunakan saat akan bekerja sesuai dengan bahaya dan risiko kerjanya untuk menjaga keselamatan pekerja dan orang lain yang ada di sekelilingnya merupakan Alat Pelindung Diri (APD).(Buntarto, 2015)

Berdasarkan Keputusan Direktorat Jendral P2PL Depkes RI Nomor 31-I/PD.03.04.LP Tahun 1993 tentang perlengkapan Alat Pelindung Diri (APD) minimal yang harus dipakai sesuai dengan jenis pekerjaan dan klasifikasi pestisida, beberapa jenis APD yang harus dipakai pada saat penyemprotan di luar gedung antara lain: penutup kepala (topi atau caping), pelindung muka atau pelindung pernapasan (masker), pakaian kerja (baju dengan lengan panjang dan celana panjang yang berbetuk terusan maupun yang terpisah), pelindung tangan (sarung tangan) dan pelindung kaki (sepatu boot yang memiliki alas panjang, terbuat dari bahan karet, tidak mudah robek serta tidak mudah mengkerut).(Anonim, 2012) 


\section{Alat pelindung diri yang seharusnya dipakai petani adalah:}

\section{Pakaian Kerja}

Berguna untuk menutupi seluruh atau sebagian dari percikan bahan beracun. Bahan bisa terbuat dari kain dril, kulit, plastik, asbes atau kain yang dilapisi aluminium. Bentuknya bisa berupa apron (menutupi sebagian tubuh yaitu mulai dada sampai lutut), celemek atau pakaian terusan dengan celana panjang, dan lengan panjang (overalls).

2. Penutup Kepala

Penutup kepala yang dipakai petani bisa berupa topi atau tudung untuk melindungi kepala dari zat-zat kimia dan kondisi iklim yang kurang mendukung. Harus terbuat dari bahan yang mempunyai celah atau lobang, biasanya terbuat dari asbes, kulit, wol, katun yang dicampur aluminium.

3. Alat Pelindung Hidung dan Mulut

Pernafasan dapat terlindungi dari bahaya berupa gas, uap, debu atau udara yang terkontaminasi di tempat kerja yang dapat bersifat racun, korosi atau rangsangan maka harus menggunakan masker. Masker dapat terbuat dari kain dengan ukuran pori-pori tertentu atau bahan lainnya sesuai dengan sifat bahan kimia yang ditangani.

4. Sarung Tangan

Berguna untuk melindungi tangan dari bahan kimia baik padat ataupun larutan. Sarung tangan bisa terbuat dari karet (melindungi diri dari paparan bahan kimia), sehingga larutan pestisida tidak dapat masuk ke kulit.

\section{Sepatu Kerja}

Berguna untuk melindungi kaki dari larutan kimia. Sepatu kerja atau sepatu boot sangat diperlukan pada penyemprotan pestisida. Bahannya bisa terbuat dari kulit, karet sintetik atau plastik. Ketika memakai sepatu boot ujung celana tidak boleh dimasukkan ke dalam sepatu, karena cairan pestisida bisa masuk ke dalam sepatu.(Khamdani, 2009)

\section{Bahan Kimia}

Bahan kimia saat ini sudah mencapai ratusan ribu jenis untuk berbagai macam kebutuhan. Diantara bahan-bahan kimia tersebut, ada yang bisa dikelompokkan sebagai bahan kimia yang tidak berbahaya dan beracun (non-B3) dan ada yang dikelompokkan sebagai bahan berbahaya dan beracun (B3).(Cahyono, 2004)

Secara umum bahan kimia yang digolongkan sebagai B3, selain bahan radiasi, memiliki karakteristik sebagai berikut: 
1. Bahan Kimia Mudah Terbakar

2. Bahan Kimia Mudah Meledak

3. Bahan Kimia Reaktif Terhadap Air

4. Bahan Kimia Reaktif Terhadap Asam

5. Bahan Kimia Korosif

6. Bahan Kimia Iritan

7. Bahan Kimia Beracun

8. Bahan Kimia Karsinogenik

9. Gas Bertekanan

10. Bahan Kimia Oksidator

11. Pengendalian bahan Kimia(Cahyono, 2004)

Proses pembelian bahan kimia menyangkut kerjasama beberapa unit kerja, yaitu pihak pengguna, bagian pembelian, bagian K3 (Keselamatan dan Kesehatan Kerja), dan bagian gudang. Bagian K3 perlu menginformasikan kepada bagian lain mengenai adanya larangan pemakaian bahan-bahan kimia tersebut. Jika bahan penggantinya belum ada, maka harus diberitahukan kepada operator tentang bahaya bahan kimia yang ada sekarang, dan bagian K3 terus mencari alternatifnya.(Cahyono, 2004)

1. Penerimaan

Penerimaan bahan kimia pada dasarnya sama dengan penerimaan bahan lain, hanya saja yang menjadi perhatian utama adalah jenis bahan kimia yang dilarang pemakaiannya, jenis bahan kimia yang mudah terbakar dan meledak, jumlah drum yang mungkin melebihi kapasitas gudang penyumpanan, spesifikasi bahan yang berbeda dengan yang diminta, label, serta cara penyimpanannya.

2. Penyimpanan

Penyimpanan bahan kimia disesuaikan berdasarkan beberapa faktor bukan pada biaya dan ruang yang tersedia, tetapi rekomendasi yang umum adalah bahan kimia harus diletakkan di tempat yang dingin, kering, ventilasi baik dan bangunannya memiliki sistem drainase yang baik, walaupun faktor-faktor penggunanya mungkin dapat dicegah sebaik mungkin. Faktorfaktor ini termasuk kuantitas yang disimpan, sifat bahan kimia, paket yang diterima, metode pengiriman internal, alat pengangkut, metode pengeluaran di titik pemakaian.

3. Penanganan

Mungkin bahaya tunggal dari penggunaan drum atau wadah lain diakibatkan oleh hilangnya sumbat atau tutup terutama dimana hanya sebagian isi yang digunakan dan sumbat tampaknya sudah dipasang dengan baik dan benar. Kebanyakan sumbat adalah baut-masuk dan jika tidak 
dipasang dengan benar, dapat kendor perlahan-lahan akibat getaran, saat dikendaraan atau truk.

Upaya-upaya harus dilakukan untuk mengajarkan pengguna wadah untuk memasukan sumbat dengan benar, setiap orang yang harus memindahkan atau menangani drum atau wadah yang sejenis harus memastikan bahwa sumbat dalam keadaan aman. Hal ini akan berjalan otomatis. Drum atau wadah lain harus selalu ditangani dengan hati-hati dan tidak boleh dikenakan kejutan fisik, kecuali untuk diangkat vertikal dan harus selalu dipindah dengan truk atau gerobak yang bentuknya khusus.

4. Label

Pelabelan bahan kimia pada drum maupun botol setidaknya harus berisi tentang:
a. Nama dagang
b. Nama bahan aktif yang utama
c. Nama dan alamat perusahaan pembuat
d. Bahaya baham kimia
e. Lambang bahaya bahan kimia
f. Cara masuk bahan kimia ke tubuh
g. Pertolongan Pertama Pada Kecelakaan (P3K)

Besarnya label tergantung pada besarnya wadah. Untuk drum 200 Liter (55 galon) besar label sekurangnya setengah halaman folio.(Cahyono, 2004)

\section{Pestisida}

1. Pengertian Pestisida

Pestisida asal kata dari pest yang berarti hama dan sida berasal dari kata caedo berarti pembunuh. Pestisida memiliki arti secara sederhana sebagai pembunuh hama. Menurut Food and Agriculture Organization (FAO) 1986 dan Peraturan Pemerintah RI No. 7 tahun 1973, campuran bahan kimia yang dipakai untuk mencegah, membasmi serta mengendalikan binatang atau tumbuhan pengganggu seperti binatang pengerat, termasuk serangga penyebar penyakit, dengan tujuan kesejahteraan manusia merupakan pestisida. Pengertian lain dari pestisida ialah zat atau senyawa kimia, zat pengatur tubuh dan perangsang tumbuh, bahan lain, serta mikroorganisme atau virus yang dipakai untuk memelihara tumbuhan (PP RI No.6 tahun 1995). USEPA menyatakan bahwa zat atau campuran zat yang digunakan untuk mencegah mengesahkan, menolak atau membasi hama pada binatang, tumbuhan dan mikroorganisme pengganggu dinamakan pestisida.(Soemirat, 2009) 
2. Fate Pestisida

Pemakaian pestisida dapat dilakukan dengan cara disemprot, ditabur, dioles dan lain-lain. Umumnya pestisida digunakan secara semprot. Setelah dilakukan penyemprotan pestisida akan dapat berada di lingkungan udara, tanah, air, tumbuhan dan manusia.(Soemirat, 2009)

3. Klasifikasi Pestisida

Pestisida dapat diklasifikasi berdasarkan organisme targetnya, struktur kimia, mekanisme dan/atau toksisitasnya.(Soemirat, 2009) Menurut organ targetnya pestisida dapat diklasifikasikan sebagai berikut :

a. Insektisida berguna untuk membasmi atau mengendalikan serangga,

b. Herbisida berguna untuk membasmi gulma,

c. Fungisida berf untuk membasmi jamur atau cendawan,

d. Algasida berguna untuk membasmi alga,

e. Avisida berguna untuk membasmi burung serta pengontrol populasi burung,

f. Akarisida berguna untuk membasmi tungau atau kutu,

g. Bekterisida berguna untuk membasmi atau melawan bakteri,

h. Larvasida berguna untuk membasmi larva,

i. Molusksida berguna untuk membunuh siput,

j. Nematisida berguna untuk membasmi cacing,

k. Ovisida berguna untuk membasmi telur,

1. Pedukulisida berguna untuk membasmi kutu atau tuma,

m. Piscisida berguna untuk membasmi ikan,

n. Rodentisida berguna untuk membasmi binatang pengerat,

o. Predisida berguna untuk membasmi pemangsa atau predator,

p. Termisida berguna untuk membasmi rayap.(Soemirat, 2009)

Departemen kesehatan 1998, menyatakan bahwa presentasi pemakaian pestisida di Indonesia sebagai berikut insektisida $55,42 \%$, herbisida $12,25 \%$, fungisida $12,05 \%$, repelen $3,61 \%$, bahan pengawet kayu 3,61\%, zat pengatur pertumbuhan 3,21\%, rodentisida $2,81 \%$, bahan perata/perekat $2,41 \%$, akarisida $1,4 \%$, moluskisida $0,4 \%$, nematisida $0,44 \%$, dan $0,40 \%$ ajuvan serta lain-lain berjumalah 1,41\%. Dari gambaran ini insektisida merupakan jenis pestisida yang paling sering digunakan.(Soemirat, 2009)

\section{Penggunaan Pestisida harus memperhatikan Prinsip 5 (lima) Tepat, yaitu:}

1. Tepat Sasaran. Tentukan jenis tumbuhan dan hama sasaran yang akan dikendalikan, misal ulat grayak pada daun kedelai, hama wereng pada padi. 
2. Tepat Jenis. Tentukan jenis pestisida apa yang harus digunakan, umumnya pestisida memiliki kekhususan terhadap jenis OPT yang dapat dikendalikan misalnya: bakterisida (pembasmi penyakit yang disebabkan bakteri), fungisida (pembasmi jamur), insektisida (pembasmi serangga), akarisida (pembasmi tungau), moluskisida (pembasmi moluska seperti keongmas), rodentisida (pengendali tikus), dsb.

3. Tepat Waktu. Waktu pengendalian ditentukan berdasarkan: a) tahap rentan dari hama yang menyerang, misalnya ulat yang masih kecil, b) banyaknya hama yang paling tepat untuk dikendalikan sesuai ambang ekonominya, misal jumlah ulat grayak 8 ekor/tanaman, c) kondisi lingkungan, misalnya jangan menggunakan pestisida pada saat hujan, kecepatan angin tinggi, cuaca panas terik, d) lakukan pengulangan sesuai dengan waktu yang dibutuhkan. Waktu aplikasi adalah salah satu faktor yang sangat menentukan efektifitas pestisida yang digunakan. Jika dikaitkan dengan tahap perkembangan hama, maka dikenal waktu aplikasi pestisida yakni 1) Aplikasi Preventif, dilakukan sebelum ada serangan hama dengan tujuan untuk melindungi tanaman, 2) Aplikasi dengan Sistem Kalender (aplikasi berjadwal, tetap banyak dilakukan oleh petani, misalnya seminggu sekali atau bahkan seminggu dua kali), 3) Aplikasi Kuratif, aplikasi ini dilakukan sesudah ada serangan hama dengan maksud untuk menghentikan serangan atau menurunkan populasi OPT, dan 4) aplikasi berdasarkan ambang pengendalian atau ambang ekonomi hama.

5. Tepat Dosis/Konsentrasi

Supaya pestisida yang diaplikasikan efektif membasmi OPT sasaran, maka dosis/konsentrasi pestisida harus ditetapkan secara tepat. Dosis merupakan banyaknya pestisida yang diperlukan untuk setiap satuan luas, misalnya dosis pestisida A sebanyak 2 L/ha, pestisida B sebanyak $250 \mathrm{~mL} /$ pohon. Sedangkan konsentrasi adalah banyaknya pestisida yang diperlukan untuk setiap satuan aplikasi, misalnya $2 \mathrm{~mL} / \mathrm{L}, 0,5 \mathrm{ml} / \mathrm{L}$. Kurangnya perhatian petani terhadap dosis/konsentrasi pestisida ini sering menyebabkan aplikasi pestisida yang salah.

6. Tepat Cara, yaitu melakukan aplikasi pestisida dengan cara yang sesuai dengan formulasi pestisida dan anjuran yang ditetapkan. Cara pemakaian pestisida di antaranya cara penaburan, cara penyemprotan, cara penghembusan, cara pengumpanan, cara fumigasi, dan cara pengasapan.

\section{Langkah-langkah Persiapan sebelum melakukan penyemprotan, antara lain:}

1. Mempersiapkan bahan-bahan pestisida yang akan dipakai (harus terdaftar), memenuhi syarat secara fisik (layak pakai), sesuai jenis dan kegunaannya, begitu juga dengan peralatan yang digunakan harus dengan cara yang akan dipakai (volume tinggi atau volume rendah). 
2. Menyiapkan kelengkapan keselamatan atau pakaian pelindung, seperti sarung tangan, masker, topi, dan sepatu kebun.

3. Mengecek alat penyemprotan dan bagiannya, guna mengetahui apakah terdapat kebocoran atau keadaan lain yang bisa mengganggu pelaksanaan penyemprotan Pestisida. Jangan pernah memakai alat semprot yang bocor.

4. Waktu pencampuran dan pemakaian pestisida sebaiknya jangan langsung memasukkan pestisida ke dalam tangki. Siapkan ember serta isi air secukupnya terlebih dulu, kemudian tuangkan pestisida sesuai dengan takaran-takaran sesuai anjuran dan aduk hingga merata. Setelah itu larutan tersebut dimasukkan ke dalam tangki dan tambahkan air secukupnya.

\section{Hal Penting yang harus diperhatikan saat Penyemprotan/Pengunaan Pestisida sebagai berikut:}

1. Pada waktu menyemprot, petani harus menggunakan perlengkapan keselamatan seperti sarung tangan, baju lengan panjang, celana panjang, topi, sepatu boot, dan masker/sapu tangan bersih untuk menutup hidung dan mulut selama aplikasi.

2. Jangan berjalan melawan arah datangnya angin serta tidak melalui area yang telah diaplikasi Pestisida.

3. Penyemprotan sebaiknya dilaksanakan pada pagi hari atau sore hari.

4. Selama menyemprot, tidak diperbolehkan makan, minum, atau merokok.

5. Satu orang operator/petani sebaiknya tidak melaksanakan penyemprotan pestisida terusmenerus $\geq 4$ (empat) jam perhari.

6. Operator/petani yang melakukan penyemprotan pestisida sebaiknya sudah berusia dewasa, sehat, tidak cacat, dan tidak dalam kondisi perut kosong.

7. Pada area yang telah disemprot dipasang tanda peringatan bahaya.

8. Bersihkan semua peralatan dan pakaian setelah menyemprot serta segera mandi.

9. Sisa campuran pestisida tidak dibiarkan/disimpan terus di dalam tangki, karena lamakelamaan akan mengakibatkan korosif atau kerusakan pada tangki. Sebaiknya sisa tersebut disemprotkan pada tumbuhan sampai habis dan jangan membuang sisa cairan semprot atau wadah kemasan pestisida di sembarang tempat, karena akan menyebabkan pencemaran lingkungan.

\section{Prosedur Pertolongan Pertama saat Kejadian Pestisida}

1. Segera bersihkan pestisida yang tertumpah.

2. Jika tertumpah sedikit, gunakan sarung tangan saat membersihkannya. 
3. Jangan menyiram tumpahan pestisida karena bisa membahayakan organisme non target, gunakan bahan yang bisa menyerap tumpahan seperti serbuk kayu atau bahan lainnya yang bisa dengan mudah dibuang pada tempat yang aman.

4. Jika tumpahan pestisida mengenai tubuh, segera bersihkan menggunakan air dan sabun atau lihat petunjuk yang ada pada label pestisida.

5. Jika terkena pakaian segera lepaskan dang anti pakaian yang terkontaminasi.

6. Jika terkena mata, siramlah mata perlahan-lahan selama sekitar 10-15 menit.

7. Jika terhirup, segera cari tempat terbuka untuk mendapatkan udara segar.

\section{METODE}

1. Identifikasi Masalah

Masalah ialah suatu hambatan atau persoalan yang harus dipecahkan, dengan kata lain masalah merupakan kesenjangan antara kenyataan dan harapan yang diinginkan dengan baik agar tercapai tujuan dengan hasil yang maksimal.

Identifikasi masalah adalah pengenalan masalah atau inventarisir masalah. Identifikasi masalah merupakan suatu proses penelitian yang paling utama diantara proses lain. Masalah penelitian akan menentukan kualitas dari penelitian. Selain itu bisa menentukan apakah sebuah kegiatan bisa disebut penelitian atau tidak. Masalah penelitian secara umum dapat kita temukan melalui studi literatur atau pengamatan lapangan (observasi, survei, dan sebagainya). Berdasarkan hasil penelitian bulan Juli tahun 2018 diperoleh bahwa dari 76 responden yang diteliti sebanyak 51,3\% responden memiliki pengetahuan kurang baik tentang Alat Pelindung Diri (APD), 51,3\% responden memiliki sikap negatif dan 98,7\% responden tidak lengkap dalam pemakaian Alat Pelindung Diri (APD).

2. Pemecahan Masalah

a. Meningkatkan pengetahuan petani mengenai manfaat Alat Pelindung Diri (APD)

b. Meningkatkan pengetahuan petani tentang bahaya pestisida

c. Meningkatkan pengetahuan petani tentang cara pemakaian pestisida yang benar

d. Menumbuhkan kesadaran pada petani untuk memakai Alat Pelindung Diri (APD) dan melakukan penyemprotan dengan benar

3. Intervensi

a. Penyuluhan/pendidikan kesehatan

b. Praktek pemakaian APD dan teknik pemakaian pestisida dengan benar

4. Sasaran

a. Petani 
b. Pemilik lahan pertanian

5. Intervensi

a. Penyuluhan dilakukan dengan metode : Ceramah, tanya jawab dan diskusi

b. Praktek pemakaian APD dan teknik pemakaian pestisida dengan benar

\section{HASIL DAN PEMBAHASAN}

\section{Hasil Pelaksanaan Kegiatan}

Kegiatan pengabdian masyarakat dilakukan dengan bentuk ceramah, diskusi dan tanya jawab dan dilanjutkan dengan praktek pemakaian Alat Pelindung Diri (APD) dan pemakaian pestisida yang benar. Rincian kegiatan ditunjukkan pada tabel 1.

Tabel 1. Rincian Kegiatan

\begin{tabular}{clrlc}
\hline Sesi & \multicolumn{1}{c}{ Kegiatan } & \multicolumn{2}{c}{ Metode } & Media \\
\hline 1 & $\begin{array}{l}\text { Penyuluhan/pendidikan kesehatan } \\
\text { tentang Alat Pelindung Diri dan } \\
\text { bahaya pemakaian pestisida }\end{array}$ & $\begin{array}{l}\text { Ceramah, tanya } \\
\text { jawab dan } \\
\text { diskusi }\end{array}$ & LCD \\
\hline 2 & $\begin{array}{l}\text { Praktek pemakaian Alat Pelindung } \\
\text { Diri (APD) dan teknik pemakaian } \\
\text { pestisida }\end{array}$ & Praktek & $\begin{array}{c}\text { Masker, topi sarung } \\
\text { tangan, sepatu boot } \\
\text { Pestisida }\end{array}$ \\
\hline
\end{tabular}

1. Penyuluhan tentang Pemakaian APD dan Bahaya Pestisida

Pengabdian masyarakat dalam bentuk penyuluhan tentang pemakaian Alat Pelindung Diri (APD) dan bahaya pemakaian pestisida merupakan langkah awal dari intervensi temuan hasil penelitian untuk menangani permasalahan yang ditemukan bahwa dari 76 responden yang diteliti sebanyak 51,3\% responden memiliki pengetahuan kurang baik tentang Alat Pelindung Diri (APD), 51,3\% responden memiliki sikap negatif dan 98,7\% responden tidak lengkap dalam pemakaian Alat Pelindung Diri (APD).

Penyuluhan tentang pemakaian APD dan bahaya pemakaian pestisida dilaksanakan pada tanggal 08 April 2019 yang dihadiri oleh Kepala Desa, pemilik lahan, dan petani. Hasil evaluasi menunjukan antusias yang cukup tinggi dari para peserta karena diskusi berjalan dengan aktif dan peserta memahami materi yang disampaikan.

2. Praktek pemakaian Alat Pelindung Diri (APD) dan Penanganan Pestisida Pada saat praktek pemakaian Alat Pelindung Diri sebagai upaya pencegahan bahaya dari pemakaian pestisida yang dapat menyebabkan keracunan, iritasi, dan dermatitis semua peserta melihat APD apa saja yang sebaiknya dipakai.

Hal-hal Yang Perlu diperhatikan saat Penyemprotan/Pengunaan Pestisida sebagai berikut: 
a. Pada waktu menyemprot, petani harus menggunakan perlengkapan keselamatan seperti sarung tangan, baju lengan panjang, celana panjang, topi, sepatu boot, dan masker/sapu tangan bersih untuk menutup hidung dan mulut selama penyemprotan.

b. Tidak diperbolehkan melawan arah datangnya angin dan tidak melalui area yang telah dilakukan penyemprotan.

c. Penyemprotan sebaiknya dilaksanakan di waktu pagi hari atau sore hari.

d. Selama menyemprot, tidak diperbolehkan makan, minum, atau merokok.

e. Satu orang operator/petani sebaiknya tidak melakukan penyemprotan pestisida terusmenerus lebih dari 4 (empat) jam perhari.

f. Operator/petani yang melaksanakan penyemprotan pestisida lebih baik yang sudah dewasa, sehat, tidak ada bagian yang luka, dan tidak dalam kondisi perut kosong.

g. Pada area yang telah disemprot dipasang tanda peringatan bahaya.

h. Bersihkan semua peralatan dan pakaian setelah menyemprot serta segera mandi.

i. Sisa campuran pestisida tidak dibiarkan/disimpan terus di dalam tangki, karena lamakelamaan akan menyebabkan tangki berkarat atau rusak. Sebaiknya sisa tersebut disemprotkan kembali pada tumbuhan sampai habis, jangan membuang sisa cairan semprot atau wadah kemasan pestisida di sembarang tempat, karena dapat menyebabkan lingkungan menjadi terkontaminasi.

\section{Pembahasan}

Penyuluhan tentang pemakaian Alat Pelindung Diri dan bahaya pestisida merupakan satu kesatuan kegiatan yang tidak bisa dipisahkan untuk menangani masalah kasus keracunan pestisida. Perilaku seseorang didasari oleh pengetahuan dan sikap sehingga untuk merubah perilaku harus diawali dari pengetahuan selain itu pengetahuan merupakan faktor predisposing dari determinan perilaku.(Notoatmodjo, 2010b)

Jika dilihat dari antusias kehadiran dan peran aktif yang ditunjukan oleh warga selama kegiatan berlangsung mulai dari penyuluhan, dan praktik pemakaian APD, menunjukkan adanya niat dan keinginan untuk melakukan pencegahan dan penanggulangan bahaya pestisida. Dengan bertambahnya pengetahuan diharapkan petani di desa Sigambir kecamatan Brebes kebupaten Brebes mampu merubah perilaku dalam pemakaian APD yang dapat menyebabkan munculnya keracunan pestisida. Perilaku pemakaian APD yang masih rendah karena kurangnya pengetahuan pada petani di desa Sigambir kecamatan Brebes kabupaten Brebes berubah menjadi lebih tinggi serta mampu mengatasi bahaya pestisida dengan cara memakai APD seadanya/sesuai kemampuan tetapi lengkap. Misalnya memakai masker jika tidak ada bisa memakai pakaian/kaos untuk 
menutup hidung agar pestisida tidak terhirup secara langsung, memakai sepatu boot, sarung tangan, baju/kaos lengan panjang, celana panjang, dan topi.

Alat Pelindung Diri (APD) memang merupakan hierarki pengendalian paling terakhir namun jika pengendalian yang lain tidak dapat diterapkan maka akan menjadi pilihan utama. Direktorat Jendral P2PL Depkes RI Nomor 31-I/PD.03.04. LP Tahun 1993 mengenai perlengkapan Alat Pelindung Diri (APD) yang wajib dipakai sesuai jenis pekerjaan dan klasifikasi pestisida, jenis-jenis APD yang sebaiknya digunakan untuk penyemprotan di luar gedung antara lain: pelindung kepala (topi atau caping), pelindung muka atau pelindung pernapasan (masker), pelindung badan (baju lengan panjang dan celana panjang yang terusan maupun yang terpisah, pelindung tangan (sarung tangan) dan pelindung kaki (sepatu boot yang memiliki alas panjang, terbuat dari bahan karet, tidak mudah robek dan tidak mudah mengkerut).(Anonim, 2012) Tetapi jika ketersediaan APD yang terbatas petani bisa memakai APD yang sederhana sesuai dengan kemampuan karena dengan begitu juga setidaknya mampu meminimalisir bahaya.

Seseorang yang telah menerima stimulus atau objek yang berkaitan dengan kesehatan, lalu melakukan persepsi atau pendapat terhadap apa yang dia ketahui, proses berikutnya diharapkan dia akan melakukan atau mempraktikan apa yang dia ketahui atau dia sikapi (nilai baik). Inilah yang disebut dengan praktik (practice) kesehatan. Sikap yang dimiliki seseorang belum tentu terbukti dalam tindakan. Agar sikap dapat dibuktikan atau diwujudkan diperlukan faktor pendukung atau suatu kondisi yang mendukung antara lain fasilitas. Apabila penerimaan perilaku dilandasi oleh pengetahuan dan sikap, kemungkinan perilaku tersebut akan bersifat langgeng.(Notoatmodjo, 2010a)

Hasil ini sejalan dengan teori bahwa ada hubungan antara pengetahuan dan sikap dengan pemakaian APD. Hal ini menunjukkan bahwa dengan pengetahuan yang tinggi serta sikap yang baik dapat menentukan perilaku seseorang baik.(Akbar, 2018)

Beberapa hasil penelitian seperti penelitian yang dilakukan oleh Ashari Rasjid menunjukan bahwa tidak ada korelasi antara pengetahuan, sikap dengan perilaku pemakaian APD. Seseorang dengan pengetahuan yang tinggi dan sikap yang baik tidak menjamin berperilaku baik.(Rasjid, Zaenab, \& Nurmin, 2019)

Secara umum pengetahuan petani mengenai pestisida sudah cukup baik namun praktik pemakaiannya kurang baik. Petani berisiko terpajan pestisida mulai dari proses pencampuran, penyemprotan sampai setelah penyemprotan. Dampak terhadap kesehatan khususnya terkait pemakaian pestisida ditemukan berkaitan dengan pemakaian pestisida golongan organophosfat, pemakaian dan pemeliharaan APD yang tidak tepat.(Minaka, A.A.S. Sawitri, \& D.N Wirawan, 2016) 


\section{KESIMPULAN DAN SARAN}

Dengan diadakannya kegiatan ini petani dan pemilik lahan mengetahui tentang manfaat pemakaian Alat Pelindung Diri (APD) dan bahaya pemakaian pestisida serta dapat membiasakan untuk memakai Alat Pelindung Diri (APD) apa saja yang sebaiknya digunakan saat melakukan penyemprotan. Adapun saran yang penulis ajukan berdasarkan hasil penelitian ini adalah:

1. Untuk Petani Desa Sigambir

Petani diharapkan tidak hanya sekedar menambah pengetahuan tetapi perlu kesadaran akan pentingnya pemakaian Alat Pelindung Diri (APD) secara lengkap pada waktu bekerja untuk keselamatan dan kesehatan kerja mereka.

2. Untuk Kelompok Tani Desa Sigambir

Menjadikan petani-petani memahami akan pentingnya pemakaian Alat Pelindung Diri (APD) dan dijadikan sebagai suatu kebiasaan dan kebutuhan petani dalam pemakaian Alat Pelindung Diri (APD) saat melakukan penyemprotan.

3. Puskesmas

Melakukan kegiatan penyuluhan mengenai keselamatan dan kesehatan kerja yang berkaitan dengan Alat Pelindung Diri dan bahaya penggunaan pestisida

\section{UCAPAN TERIMA KASIH}

Penulis menyampaikan terima kasih pada Kepala Desa Sigambir, Petani (pemilik lahan pertanian) dan petani (buruh tani) atas kerjasamanya sehingga kegiatan ini bisa berjalan dengan lancar.

\section{DAFTAR PUSTAKA}

Aeni, H. F. A., \& Nurfadillah, N. (2018). Hubungan Antara Pengetahuan dan Sikap dengan Perilaku Penggunaan APD pada Petani Pengguna Pestisida. Medical Science Jurnal Ilmiah Kefarmasian, 3(1).

Akbar, F. (2018). Hubungan Antara Pengetahuan dan Sikap Dengan Pemakaian APD (Alat Pelindung Diri) Pada Petani Bawang di Desa Bojongnangka.

Anonim. (2012). Faktor-Faktor yang Berhubungan dengan Keracunan Pestisida. Retrieved from http://www.indonesian-publichealth.com/2012/12/mencegah-keracunan-pestisida.html.

Anonim. (2018). Kabupaten Brebes. Retrieved from https://id.wikipedia.org/wiki/Kabupaten_Brebes.

Buntarto. (2015). Panduan Praktis Keselamatan dan Kesehatan Kerja Untuk Industri. Yogyakarta: Pustaka Baru Press.

Cahyono, A. B. (2004). Keselamatan Kerja Bahan Kimia Industri. Gadjah Mada University Press. 
Khamdani, F. (2009). Hubungan Antara Pengetahuan dan Sikap dengan Pemakaian Alat Pelindung Diri Pestisida Semprot pada Petani di Desa Angkatan Kidul Pati Tahun 2009. Universitas Negeri Semarang.

Minaka, I. A. D. A., A.A.S. Sawitri, \& D.N Wirawan. (2016). Hubungan Penggunaan Pestisida dan Alat Pelindung Diri dengan Keluhan Kesehatan pada Petani Hortikultura di Buleleng, Bali. Public Health and Preventive Medicine Archive Jornal., 4.

Notoatmodjo, S. (2010a). Promosi Kesehatan dan Perilaku Kesehatan. Jakarta: Rineka Cipta.

Notoatmodjo, S. (2010b). Promosi Kesehatan Teori dan Aplikasi. Jakarta: Rineka Cipta.

Purwati, A. (2010). Pestisida Ganggu Kesehatan Petani.

Rasjid, A., Zaenab, \& Nurmin. (2019). Hubungan Antara Perilaku Dengan Penggunaan Alat Pelindung Diri Pada Petani Pengguna Pestisida Di Desa Tonrong Rijang Kecamatan Baranti Kabupaten Sidenreng Rappang. Journal Medika Kesehatan Politeknik Kesehatan Makassar., 14.

Shobib, M. N. (2013). Hubungan Antara Pengetahuan dan Sikap dengan Praktik Pemakaian Alat Pelindung Diri (APD) Pada Petani Pengguna Pestisida di Desa Curut Kecamatan Penawangan Kabupaten Grobogan. 1-5.

Soedirman. (2014). Kesehatan Kerja Dalam Perspektif Hiperkes dan Keselamatan Kerja. Erlangga.

Soemirat, J. (2009). Toksikologi Lingkungan. Yogyakarta: Gajah Mada University Press.

Universitas Indonesia. (2018). Industrial Chemical Hygiene, Safety, and Security. Universitas Indonesia. 